\title{
Serial dexamethasone suppression tests in depressed patients treated only with electroconvulsive therapy
}

\author{
Leon Grunhaus, Thomas Zelnik, A. Ariav Albala, David Rabin, Roger F. Haskett, \\ Athanasios P. Zis and John F. Greden \\ Clinical Studies Unit, Department of Psychiatry, University of Michigan Medical Center, Ann Arbor, MI 48109, U.S.A.
}

(Received 1 April 1987)

(Accepted 10 June 1987)

\section{Summary}

Several systematic studies have evaluated serial dexamethasone suppression tests (DST) in patients with major depression who were treated with antidepressant medications. DST changes were noted to parallel clinical improvement in most recovering patients. If serial DSTs are a valid state-related correlate of depressive pathophysiology, all types of effective antidepressant treatment should result in DST 'normalization'. However, no treatment modalities other than antidepressant medications have been studied serially with systematic assessments. To test whether serial DSTs reflect clinical progress in depressives treated solely with electroconvulsive therapy (ECT), we studied weekly DSTs and Hamilton Rating Scales for Depression (HRSD) in 22 drug-free depressed patients. We observed progressive DST 'normalization' in most patients and moderately high correlations between weekly DST and HRSD values throughout treatment. Most patients receiving ECT became DST suppressors. In most patients the DST appeared to reflect the severity of depressive pathophysiology, perhaps providing serial feedback to clinicians monitoring the progress of treatment with ECT.

Key words: Dexamethasone suppression test; Major depression; Electroconvulsive therapy

\section{Introduction}

A number of investigators have reported on the patterns of dexamethasone suppression test (DST)

Address for correspondence: Leon Grunhaus, M.D., Assistant Professor of Psychiatry, Department of Psychiatry, University of Michigan Medical Center, Ann Arbor, MI 48109. 0118 , U.S.A.

Supported in part by NIMH Grants MH28294 and MH39593, and by the University of Michigan Mental Health Research Institute and Department of Psychiatry. results in depressed patients during treatment with antidepressant medications (Carroll 1972; De La Fuente and Rosenbaum 1980; Greden et al. 1980, 1983; Holsboer et al. 1982, 1983; Targum 1983; Gerken et al. 1985; Bowie and Beaini 1985; Baumgartner et al. 1986; Grunhaus et al. 1987). From these studies it appears that the normalization of a previously nonsuppressive DST parallels a successful course of antidepressant treatment. Initial reports suggested that similar patterns of normalization occurred during electroconvulsive 
therapy (ECT) (Dysken et al 1979 Greden and Carroll 1979 4lbala et al 1981 Papakostas et al 1981) Howerer more recent publications hate not demonstrated an association betueen DST normalization and outcome from ECT (Corvell 1986. Debanand et al 1987)

To further examine the eftects of ECT on DST results we studied 22 severelv depressed patients treated with ECT only with weekls DSTs and concurrent slınical ratıngs betore during and immediately after ECT treatment $W^{\prime}$ e addressed the following yuestions (1) Do pretreatment nonsuppressise DST, normalize over tume as ECT is admunistered" (2) If so do serial DST, have a state-relationship "ith clinical improrement" (3) Are absolute post-dexamethasone plasma cortisol ialues clinually meanıngful in monitoring clinical progress of patients treated with ECT?

\section{Methods}

Twenty-two depressed patients were hospitalized in the Clinical Studies Lnt for Aftectise Disorders (CSU) or the Clinical Psychobiology Program in the Department of Psychiatry of the Unitersill of Michigan Medical Center between 1979 and 1984 Selected demographic and clinical features for each pattent are summarized in Table 1

Each patient received our standard research diagnostic eraluation (1) a 10-14 day drug-free period ol eraluation (2) two or three unstructured clinical interneus (Including at least one evalua(1on bv a senior staff psychatrist) (3) a structured diagnostic intervieu br a traned interviewer using the Schedule for Alfective Disorders and Schizophrenia (Spitzer and Endicolt 1975). (4) phisical

TABLE I

DEMIOGRAPHIC AND CLINICAL FEATLIRES OF INDIUIDUAL PATIENTS

\begin{tabular}{|c|c|c|c|c|c|c|c|c|c|}
\hline \multirow[t]{2}{*}{ Cave } & \multirow[t]{2}{*}{$\begin{array}{l}\text { Age } \\
\text { rearul }\end{array}$} & \multirow[t]{2}{*}{ Sex } & \multirow{2}{*}{$\begin{array}{l}\text { Pre-ECT } \\
\text { weight } \\
\text { (kg) }\end{array}$} & \multicolumn{3}{|c|}{$\begin{array}{l}\text { Current epinode of } \\
\text { depression }\end{array}$} & \multicolumn{2}{|c|}{$\begin{array}{l}\text { Previsua histon of } \\
\text { deprenston }\end{array}$} & \multirow[t]{2}{*}{$\begin{array}{l}\text { Menopausal } \\
\text { status" }\end{array}$} \\
\hline & & & & $\begin{array}{l}\text { Duration } \\
\text { (month-) }\end{array}$ & $\begin{array}{l}\text { Pre-ECT drug } \\
\text { re-ponsisenes }\end{array}$ & $\begin{array}{l}\text { Duration } \\
\text { (rears) } \\
\text { ince } \\
\text { oncel }\end{array}$ & $\begin{array}{l}\text { Number ot } \\
\text { prevous } \\
\text { eprodes }\end{array}$ & $\begin{array}{l}\text { Presious }{ }^{3} \\
\text { responwsenes } \\
\text { to ECT }\end{array}$ & \\
\hline 1 & 70 & $F$ & 643 & 2 & NR & 4 & 2 & $\mathrm{R}$ & PMI \\
\hline 2 & $\geq 1$ & $\mathrm{~F}$ & 689 & 9 & NR & b & 5 & - & PMI \\
\hline 3 & 47 & $\mathbf{M}$ & 793 & 18 & NR & 20 & 4 & $\mathrm{R}$ & - \\
\hline 4 & 69 & $F$ & nos & 4 & NR & 3 & 4 & $\mathrm{R}$ & $\mathrm{PM}$ \\
\hline , & 28 & $\mathrm{~F}$ & 497 & 6 & NR & 2 & 2 & - & $\mathrm{TAH}$ \\
\hline 6 & t.6 & $F$ & $46 U$ & 36 & - & 12 & 13 & $\mathbf{R}$ & PMI \\
\hline 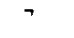 & 811 & $F$ & 431 & 10 & - & 3 & 1 & - & PMI \\
\hline$\&$ & 58 & $F$ & 620 & 24 & NR & 2 & 0 & - & PN1 \\
\hline 9 & 34 & $M 1$ & 658 & 12 & NR & 1 & 11 & NR & - \\
\hline 10 & $2 x$ & $\Lambda 1$ & 748 & 1 & $N R$ & 2 & 1 & - & - \\
\hline 11 & 69 & $M$ & 797 & 2 & - & 1 & 1 & - & - \\
\hline 12 & 34 & $\mathrm{~F}$ & 767 & 4 & - & $1(1$ & 2 & $\mathrm{R}$ & 4 \\
\hline 13 & 1.4 & $F$ & $x(1) 3$ & 12 & NR & 26 & 3 & - & $\mathrm{T}+\mathrm{H}$ \\
\hline 14 & $6 x$ & $\mathrm{~F}$ & 235 & 6 & - & 6 & u & - & PMI \\
\hline 19 & 62 & $M 1$ & 811 & us & - & 10 & 3 & $\mathrm{R}$ & - \\
\hline 16 & 43 & $\mathbf{M}$ & 678 & 3 & NR & 24 & $>10$ & $\mathrm{R}$ & - \\
\hline 17 & 63 & $\mathrm{~F}$ & 409 & 2 & NR & 3 & 4 & $\mathbf{R}$ & PMI \\
\hline In & 63 & $\mathrm{~F}$ & 469 & 1 & - & 33 & 5 & $\mathrm{R}$ & PM1 \\
\hline 19 & 64 & $F$ & 762 & 1 & - & 108 & 0 & - & ТАH \\
\hline 201 & 19 & $F$ & 463 & 4 & - & 23 & 4 & $\mathbf{R}$ & PM1 \\
\hline 21 & 61 & $F$ & 456 & 11 & NR & 20 & $>10$ & - & $\mathbf{P M}$ \\
\hline 22 & th & $\mathrm{F}$ & 653 & 6 & NR & 40 & 3 & $\mathrm{R}$ & PMI \\
\hline
\end{tabular}

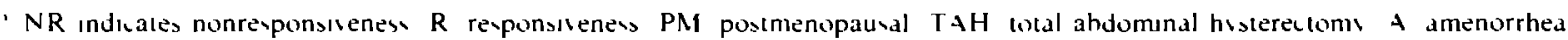


examination and comprehensive laboratory screenıng to rule out serious medical illnesses (5) famly interveus to validate longitudinal histor and (6) revieus ol previous medical records Following collection of information consensus diagnoses were compiled using Research Diagnowic Criteria (RDC) (Spitzer et al 1975 Carroll et al 1980) Diagnosticians always were blınd to DST results

Inclusion criteria were (1) severe depressite simptoms treated exclusiselv uith ECT (2) weekls DSTs prior to and during ECT treatment (3) no technical source of vanance that would inialidate ans of the DSTs (Carroll et al 1981), including no serious medical illness no history of severe weighi loss (greater than $20^{\circ}$ c helow normal bod weight) no alcoholusm or drug abuse no pregnancy and no treatment with insalidating drugs including carbamazepine (Privitera et al 1982) (4) weekl 17-Item Hamiton Ratıng Scale for Depression (HRSD) completed by raters blınd to DST result, (Hamulton 1960) (5) no treatment with ans psichoactise medication during the course of ECT fother than those necessan for the admumistration of ECT), and (6) informed consent to participate in research All patıents who met these criteria were included in the sample

Tuentv-one of 22 patients (Table 1 ) met RDC crileria for major depressive disorder (MDD) endogenous subtype Of these $17\left(81^{\circ}\right)$ had delusional simptoms Four unipolar patients ( $\mathrm{Nos}$ 121718 and 22) were nondelusional Patıent No 9 recerved a diagnosis of schizoaffectuse (disorder) depressed Patient No 6 had a history of bipolar illness Serenty-one percent of the total sample uere female The mean age $( \pm S D)$ for the enture

TABLE 2

DST AND HRSD \ ALLIES FOR INDILIDU AL PATIENTS ST AND ARDIZED SERIAL TIMIE POINTS

\begin{tabular}{|c|c|c|c|c|c|c|c|c|c|c|}
\hline \multirow[t]{2}{*}{ Cane } & \multicolumn{2}{|l|}{ Pre-ECT } & \multicolumn{2}{|c|}{ One-thurd } & \multicolumn{2}{|c|}{ Two ihird, } & \multicolumn{2}{|c|}{ Post ECT } & \multirow{2}{*}{$\begin{array}{l}\mathrm{E}(\mathrm{T} \\
\text { receised }(n)\end{array}$} & \multirow{2}{*}{$\begin{array}{l}\text { Clinied } \\
\text { response }\end{array}$} \\
\hline & $\mathrm{HRSD}^{\circ}$ & $\overline{\text { DST }^{\wedge}}$ & HRSD & $\overline{\mathrm{DST}}$ & HRSD & $\overline{\text { DST }}$ & HRSD & $\overrightarrow{\mathrm{DST}}$ & & \\
\hline 1 & 30 & 134 & 22 & 42 & 6 & 19 & 6 & 14 & II) & $\mathbf{R}$ \\
\hline 2 & 36 & $7+7$ & 29 & 21 & 20 & 12 & 2 & 10 & 12 & $\mathbf{R}$ \\
\hline 3 & 40 & 60 & 29 & U 3 & 27 & 110 & 31 & 15 & $1^{7}$ & NR \\
\hline 4 & 32 & 134 & 32 & 239 & - & - & + & 22 & h & $\mathrm{R}$ \\
\hline 2 & 30 & 99 & 26 & 1107 & 2 & $>3$ & 1 & 119 & 4 & $\mathrm{R}$ \\
\hline 0 & $1 x$ & 799 & 10 & บ9 & $=$ & $3 u$ & 3 & $1^{7}$ & , & $\mathbf{R}$ \\
\hline$\neg$ & 21 & 164 & 2 & 26 & 2 & 114 & 1 & 22 & 6 & $\mathbf{R}$ \\
\hline$x$ & 42 & 60 & 29 & 92 & 16 & 27 & 13 & $1+$ & 12 & Purtual \\
\hline 9 & is & 40 & $h$ & 116 & 6 & 04 & 4 & 11 & h & R \\
\hline 10 & 34 & 3 & 22 & $7 h$ & - & 11 & 21 & 13 & IV & NR \\
\hline 11 & 23 & $6^{7}$ & 10 & 27 & 4 & 132 & 21 & 14 & כ & Dixinlinued \\
\hline 12 & 32 & 16. & 16 & 101 & 14 & 12 & 9 & 11 & 7 & $\mathbf{R}$ \\
\hline 13 & 19 & $\times 4$ & 16 & 63 & 11 & 13 & 6 & 26 & $x$ & $\mathbf{R}$ \\
\hline 14 & 23 & 24 & 14 & 117 & 9 & 24 & 4 & 12 & 6 & $\mathbf{R}$ \\
\hline 15 & - & 129 & - & - & 16 & 111 & 3 & 13 & h & $\mathbf{R}$ \\
\hline 16 & 26 & 128 & $2 h$ & 96 & 16 & 311 & - & 11 & h & Withdren \\
\hline 17 & 23 & 246 & 9 & 138 & 4 & 70 & 15 & 120 & - & $N R$ \\
\hline $1 x$ & 2) & $\delta>$ & 9 & 29 & ובי & 115 & 12 & - & $1 x$ & Partlal \\
\hline 19 & 19 & 134 & 21 & 111 & 15 & 128 & 4 & 120 & 9 & $\mathbf{R}$ \\
\hline 20 & 32 & 129 & 32 & 124 & $1+$ & 20 & 3 & 13 & 9 & $\mathbf{R}$ \\
\hline 21 & 14 & 99 & 21 & 50 & 17 & 132 & 7 & 31 & 14 & $\mathrm{R}$ \\
\hline 22 & 37 & $2+2$ & 29 & $1 \times 0$ & 211 & 130 & 12 & $=1$ & 111 & Partial \\
\hline Mean & 277 & 93 & 154 & 77 & 123 & 12 & 48 & 27 & & \\
\hline $\begin{array}{l}\text { Siandard } \\
\text { dewa- } \\
\text { lion }\end{array}$ & 77 & 68 & 98 & 61 & 72 & 20 & 7.3 & 32 & & \\
\hline
\end{tabular}

- HRSD indicates Hamilion Raung Scale for Deprewion scores DST maximum powt-desamethawne flasma wriml walues $1 \mu \mathrm{g}$ dl, $\mathrm{R}$ responsilenes, NR nonresponsileness 
group was $576 \pm 130$ vears (range $28-80$ )

The mean weight tor the total sample "as 626 hg "ithun ideal bod weight ranges adjusted for age and height in this group ot pattents lassumed (1) be of medium (rame) Nean pretreatment HRSD (17-11em scale) score was $277 \pm 77$ (range 1S-42) pretreatment HRSD scorev tor indisidual vublects are listed in Table?

\section{Dexamethasone suppression rests}

A standardized DST approach "as used for all ubjects (Carroll et al 1981, W'e admunistered oral dexamethasone $(1 \mathrm{mg})$ at $2330 \mathrm{~h}$ each week and collected plasma samples tor cortusol the tollowing dar at 1600 and $2300 \mathrm{~h}$ Samples were awaled for cortisol using a modification of Murphis competitue protem-binding technique (CPB) (Murphs 1967) Our inter-assay and intraassall coetficients of barlation were $78^{\circ}$ r and $69^{\circ} r$ respectirely

Paltents were categorized as DST nonsuppresor it elther their 1600 or $2300 \mathrm{~h}$ pretreatment DST value exceeded $5 \mu \mathrm{g}$ dl Our reference value of $5 \mu \mathrm{g}$ dl was previousl determined bi utilızıng the (PB aisay for cortisol in our clinical populatlons ol depressed and nondepressed psichiatric patients as well as local normal controls Fise pattents recested more than one drug-tree DST betore ECT uas initiated

\section{Clmual ratming classitication and viltome}

The 17-item HRSD concided with weehly DSTs and both were always pertormed on dass between EC $T$ treatments

Whe uperaltonally delined treatment response using HRSD scores Pattents were considered good responders if they had al least a $50^{c}$ c reduction in HRSD score and a tinal HRSD ialue lew than 10 partial responders if ther had at least $50^{\circ}$ r reducIitin in the HRSD score but the final value was more than 10 and nonresponders it ther had neither Response is tabulated in Table ?

To minımize problems associated with isolated interpretation of group data clinical and neuroendocrine outcomes were evaluated for both indisidual patiente and tor the group as a whole

The total number of ECT treatments was determuned clincalls To standardize the timing of sersal assessments we analyzed HRSD and DST outcome variables tor the group at four time points 11 immediately prior to the first ECT treatment (2) upon completion of one-thurd of the clinicall determuned ECT course for each patient (3) upon completion of two-thirds of the ECT course and (4) within 1-3 dass following the last ECT treatment

\section{Electroconeulste treutment}

The clinical indications for ECT in these pdtients uere combinations of setere depresston the presence of delusional teatures previous poor reiponse 10 medication or prior good response to EC"T

Electrical impulses generated by a Medoratt instrument were administered bitemporally in all but one case ipatient No 8 recested unilateral treatmen(y) Seizure acturity was recorded in all canes with the use of a limb tournquet and or simultaneous EEG recordings Standard anesthetic pretreatment included use of a short-acting barbiturate to induce sleep (arerage dose $=075$ $\mathrm{mg}$ ' $\mathrm{kg}$ ) succinylcholine for muscle paralysis (aserage dose $=1 \mathrm{mg} / \mathrm{kg}$ ) and glycopvrrolate (average dose $=03 \mathrm{mg} 45 \mathrm{mun}$ prior to (reatment) to reduce secretions

No antidepressant antupsichotic or sedativehypnotic medications were adminstered for at least 10 days prior to ECT or at anı point during the treatment course Thus conditions were not contounded by concomitant somatic treatments

The total number of electroconvulsise treatments admunstered to each patient is listed in Table 2 ECT treatnients were administered independently from DST results The trequency is indicated by arrous on the horizontal aus for each pattent in Fig 2 For pattent No 11 treatments were discontinued after fise EC T due 10 mental confusion Patient No 16 withdrew consent after receiving six ECT Final outcome variables for patients Nos 11 and 16 are excluded from all analyses of aggregate data

Sertal ECT, DST data trom one patient (No 2) appeared in an earlier report (Albala et al 1981)

\section{Dala analises}

All DST values were log-transformed to obtain normality of distribution and equality of variances before statistical andisses were pertormed To de- 
termine the significance of decredses in DST values and HRSD scores over time during ECT treatment one-way ANOVA with repeated measures "is used parred $t$-tests were used for parametric comparisons between pre- and posttreatment DST and HRSD results, respectively For dichotomous variables we used enther the chi-squared test or Fisher's exact probability test Pearson's product-moment correlations were used to assess the relatıonship between DST values and HRSD scores for each individual patient during the course of EC T treatment

\section{Results}

Serial changes in mean post-de xamethasone calues during $E C T$

Mean post-dexamethasone plasma cortisol values and HRSD scores at the four standardized serial tıme points during ECT treatment are shou $n$ in Fig 1

These aggregate data indicate that progressive normalization of the DST occurred during resolution of the depressite syndrome with treatment One-uay ANOV'A with repeated measures confirmed significant reductions in these scores over tıme $(P<0001)$ Pairu ise comparisons betueen pre- and post-ECT treatment values confirmed highly significant reductions $(P<0001)$ in both DST and HRSD scores

Changes in the percent of DST nonsuppressors over time

Table 3 reveals that when data were analyzed categorically (suppressors is nonsuppressors de-

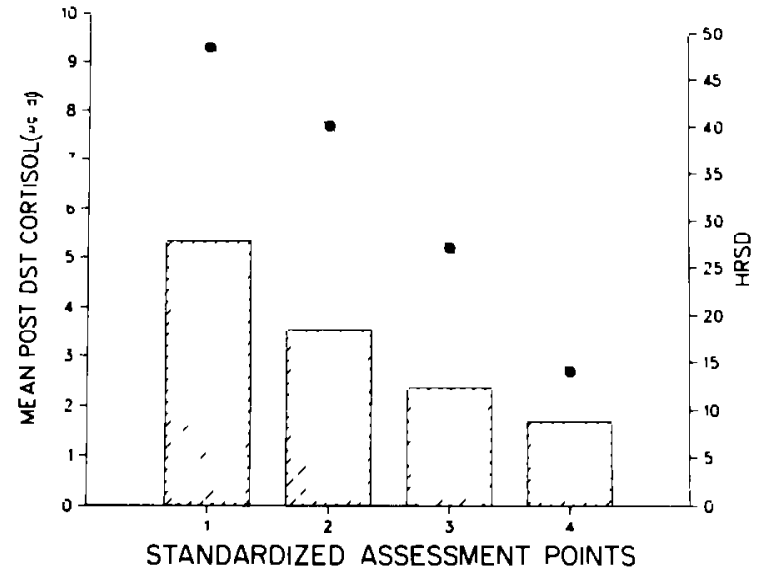

Fig l Mean post-dexamethawne plasma cortivol consentratuons in $\mu \mathrm{g}$ dl (solid circles) and Hamition Ratung Suale for Depression scores inertical halched barsl for tolal sample at four ume poins 11 , immediatel pror II FCT 1?) after completion of one-third of the course of ECT (3) alter com pletion of tho-therds of the course of ECT 14) $1-3$ dass alter lasi EC T

pressed is euthymic) there was a steady decrease In the percentage of both nonsuppressors and depressed patients during treatment Thus categoncal analyses supported trends from mean data

Comparison of responders e's nonresponders

Thurteen patuents (Nos $1224456,7,912$ $1314,15,20$ 21) had posttreatment DST suppression DSTs and good response Three pattents (Nos 3.8.10) had postlreatment DST suppression but only partual or nonresponse Three patıents had posttreatment DST nonsuppression, of these

$T \rightarrow B L E 3$

NUMBERS AND PERCENTAGES OF PATIENTS WHO ARE DST NONSUPPRESSORS AND DEPRESSED AT STANDARDIZED SERIAL TIME POINTS

\begin{tabular}{|c|c|c|c|c|}
\hline & $\begin{array}{l}\text { Immediate } \\
\text { pre-ECT }\end{array}$ & One-thırd ECT & Tuo-thurds ECT & $\begin{array}{l}\text { Immediate } \\
\text { post-ECT }\end{array}$ \\
\hline \multicolumn{5}{|c|}{ DST nonsuppressile ${ }^{*}(2 \mu \mathrm{g}$ dl $)$} \\
\hline$n$ & 20,22 & 14,21 & 821 & 319 \\
\hline$\sigma_{c}$ & 909 & 667 & 381 & 158 \\
\hline \multicolumn{5}{|c|}{ Depressed ** $($ HRSD $>10)$} \\
\hline$n$ & 22,22 & $16 \quad 21$ & 1321 & 0,20 \\
\hline$q$ & 100 & 762 & 619 & 30 \\
\hline
\end{tabular}

* Chu-square $=2674$ df $-3 \quad P<0001$

* Chu-square $=2457 \quad$ df $=3 \quad P<0001$ 


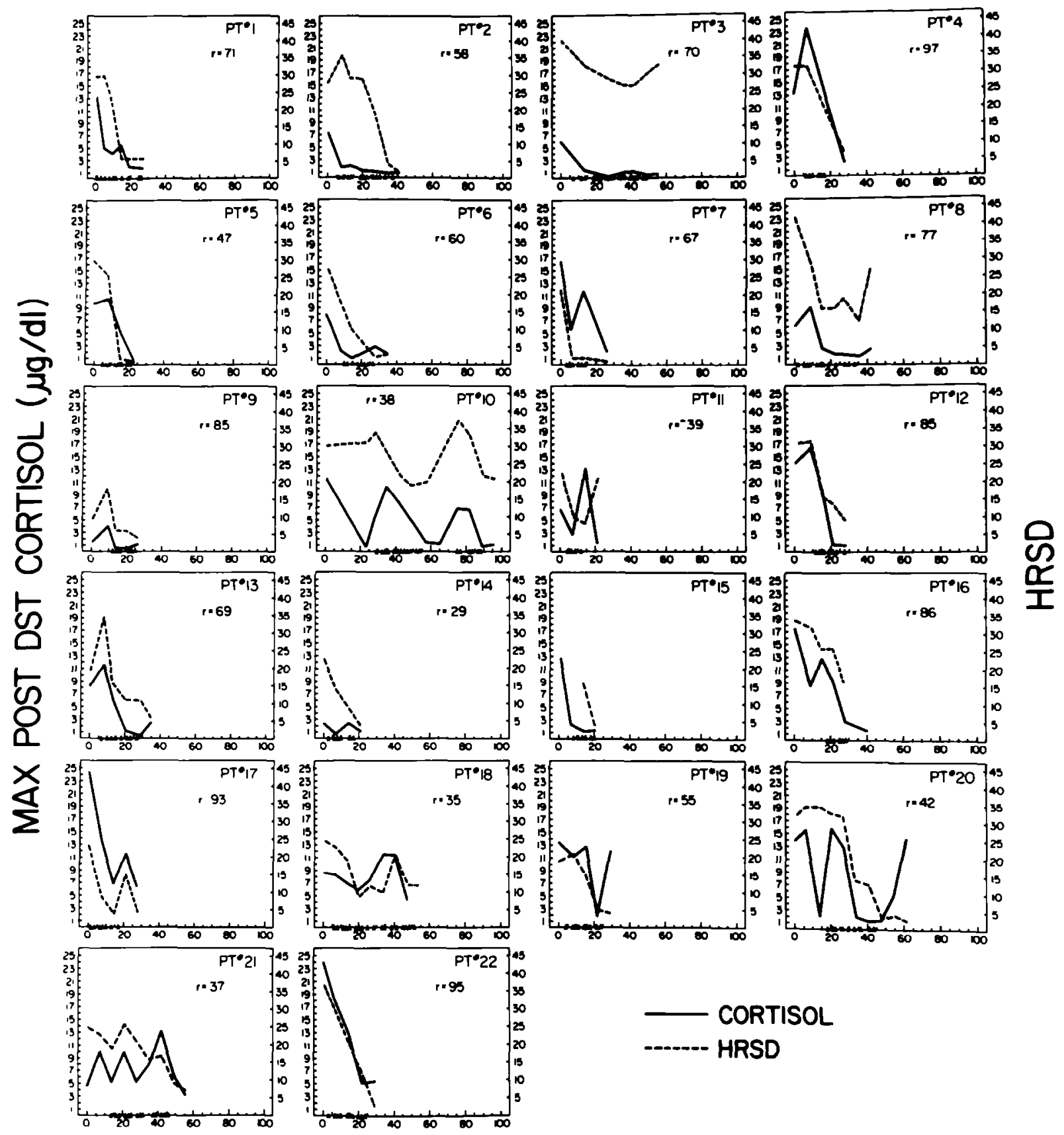

TREATMENT COURSE (Days)

Fig 2 Serial post-desamethasone plasma cortivel values iDSTI and matchıng Hamılton Ratıng Suale fir Depression ıHRSD) wore,

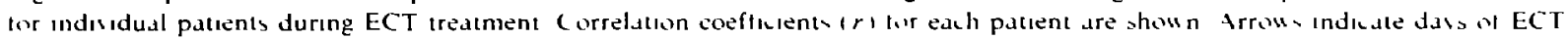
treatments 
two (Nos 17 22) had partial or nonresponse clinıcall whle one (No 19) had good outcome Three pattents were not considered in this analyss because their ECT treatments were discontınued (Nos 1116 as explanned previoush) or ther had missing data (No 18) In summan 13 of 16 pattents $\left.(81)^{\circ}\right)$ with posttreatment DST suppression had a good outcome compared with one of three pattents $\left(33^{c_{c}}\right)$ who had posttreatment DST non uppression and good outcome (Fisher s exact = 1) $15 \mathrm{~N} \mathrm{~S}$, Stated differently among good ECT responders 13 of $14\left(93^{\circ} c\right)$ were DST suppressors

\section{Indurdual patterns of serial DST and HRSD mea- surements during ECT treatment}

Gibbons and Davis (1984) have emphasized that analisis of mean values of repeated observations over tume may lead to a signuficant loss of within-subject information To address this possibility, we plotted each patient separately and examined serial post-dexamethasone plasma cortisol values and matchıng HRSD scores ( $F$ Ig 2) A rather strong temporal association between DST values and HRSD scores was evident in many pattents

Individual plots of weekly DST values and HRSD scores for each patient revealed significant between-subject iariation in patterns of association between these two rariables (Fig 2) Inspection reveals that most patients had individual patterns of DST normalization and clinical improvement which roughly paralleled the aggregate pattern shown in Fig 1

Suggestive oscillatung rhythms of post-devamethasone plasma cortisol were noted in some patients (e g. Nos 10, 17 21)

\section{W'eight as a confounding curiable}

We studied weekly weights for each of the subjects in thus study to determine the extent to which they influenced serial DST findings (Berger et al 1982. Edelstem et al 1983 Feinberg and Carroll 1984) The mean weight for the enture group changed from $626 \mathrm{~kg}$ before treatment to $615 \mathrm{~kg} 638 \mathrm{~kg}$ and $651 \mathrm{~kg}$ respectively at one-third, two-thirds and post-ECT treatment Thus mean weight continued to fall eren after inıtual ECT treatments whule mean DST values had begun to normalize (Figs 1 2) Thus aggregate data generally confirmed a lack of association between DST ralues and weight change during ECT treatment

\section{Discussion}

These data indicate that electroconiulsite theraps induces patterns of DST normalization comparable to those observed in patients treated with antidepressant medication This tinding supports a collection of prior reports (De La Fuente and Rosenbaum 1980 Greden et al $1980 \quad 1983 \quad$ Albala et al 1981 Holsboer et al 19821983 Targum 1983) that in a large proportion of patients the DST is a state-related marker of depressise pathophrsiology It also ungests that normalization of the DST is not simpli a contounded result stemming from administration of antidepressant medications orer tume

Our findings also illustrate that weekly HRSD cores and matching DST values are moderately to stronglv correlated and that most pattents recersing ECT become DST suppressors This project encountered a problem similar to that obseried in most senal DST studies I e only a limited number ot subjects tall to normalize when given eftectuve treatment limitung the power of statistical analvists Thus considerations about fallure to normalize of the DST and poor outcome contmue to be tenuous

Clinicians could benefit greatly from independent objective markers' that would and idenutication of patients most likely to respond to ECT (Hasketl 1982 Haskelt and Albala 1982) or in determining the opumal number of ECT treatments These DST data strengthen pilot reports that suggest that responders to ECT are more likely to become devamethasone suppressors DST changes mav provide biological confirmation of clinical progress in most patients but we caution against over-interpretation Normalization of the DST does not almars predict good clinical outcome and peristent DST nonsuppression during ECT does not aliais preclude clinical improvement during treatment Some of the discrepancies tound between studies might be clarified bi longer periods of obseriation follouing recover from depression It is well known that remussion from a depressive episode does not follow a uniform pattern across pattents It may well be that a similar 
process occurs with the DST. Further refinements of research strategies are needed to address unanswered questions. For example, this study should be repeated with concomitant plasma dexamethasone levels to control for the possibility that repeated administration of barbiturates for ECT might change dexamethasone metabolism. If so, however, we would have expected to find progressively more nonsuppression, exactly opposite to what we observed. Finally, serial DSTs in untreated patients, i.e., those involved in placebocontrolled studies, may provide information on the 'naturalistic' course of hypothalamicpituitary-adrenal axis dysfunction in depression.

\section{References}

Albala, A.A., Greden. J.F., Tarika, J. and Carroll, B.J., Changes in serial dexamethasone suppression tests among unipolar depressives receiving electroconvulsive treatment, Biol. Psychiatry, 16 (1981) 551-560.

Baumgartner, A., Graff, K.J. and Kurten, I., Serial dexamethasone suppression tests in psychiatric illness, Psychiat. Res., 18 (1986) 2543 .

Berger, M., Doerr, P., Lund, R. et al., Neuroendocrinological and neurophysiological studies in major depressive disorders: are there biological markeis for the endogenous subtype?, Biol. Psychiatry, 17 (1982) 1217-1242.

Bowie, P.C.S. and Beaini, A.Y., Normalization of the dexamethasone suppression test, Br. J. Psychiatry, 147 (1985) $30-35$.

Carroll, B.J., The hypothalamic-pituitary-adrenal axis in depression. In: B.M. Davies, B.J. Carroll and R.M. Mowbray (Eds.), Depressive Illness: Some Research Studies, C.C. Thomas, Springfield, IL, 1972, pp. 23-201.

Carroll, B.J., Feinberg, M., Greden, J.F. et al., Diagnosis of endogenous depression, J. Affect. Disord., 2 (1980) 177-194.

Carroll, B.J., Feinberg, M., Greden, J.F. et al., A specific laboratory test for the diagnosis of melancholia, Arch. Gen. Psychiatry, 38 (1981) 15-22.

Coryell, W., Are serial dexamethasone suppression tests useful in electroconvulsive therapy?, J. Affect. Disord., 10 (1986) $59-66$.

Dc La Fucnte, J.R. and Rosenbaum, A.H., Neuroendocrine dysfunction and blood levels of tricyclic antidepressants, Am. J. Psychiatry, 137 (1980) 1260-1261.

Debanand, D.P., Decina, P., Sackeim, II.A., IIopkins, N., Novacenko, H. and Malitz, S., Serial DST's in initial suppressors and non-suppressors treated with electroconvulsive therapy, Biol. Psychiatry, 22 (1987) 463-472.

Dysken, M.W., Pandey, G.N., Chang, S.S. et al., Serial postdexamethasone cortisol levels in a patient undergoing ECT. Am. J. Psychiatry, 136 (1979) 1328-1329.

Edelstein, C.K., Roy-Byrne, P., Fawzy, F.I. and Dornfeld, L., Effects of weight loss on the dexamethasone suppression test, Am. J. Psychiatry, 140 (1983) 338-341.

Feinberg, M. and Carroll, B.J., Biological 'markers' for endog- enous depression - effect of age, severity of illness, weight loss, and polarity, Arch. Gen. Psychiatry, 41 (1984) 1080-1085.

Gerken, A., Maier, W. and Holsboer, F., Weekly monitoring of DST suppression response in depression. Psychoneuroendocrinology. 10 (1985) 261-271.

Gibbons, R.D. and Davis, J.M., The price of beer and the salaries of priests: analysis and display of longitudinal psychiatric data, Arch. Gen. Psychiatry. 41 (1984) $1183-1184$

Greden, J.F. and Carroll, B.J., The dexamethasone suppression test as a diagnostic aid in catatonia. Am. J. Psychiatry. 136 (1979) 1199.

Greden, J.F., Albala, A.A., Haskett. R.F. et al., Normalization of the dexamethasone suppression test: a laboratory index of recovery from endogenous depression, Biol. Psychiatry. 15 (1980) 449-458.

Greden, J.F., Gardner. R., King. D. et al., Dexamethasone suppression tests in antidepressint treatment of melancho. lia: the process of normalization and test-retest reproducibility. Arch. Gen. Psychiatry, 40 (1983) 493--500.

Grunhaus, L., Flegel, P., Pande, A., Kotun, J. ,Haskett, R.1 and Greden, J.F., DST nonsuppression predicts outcome in MDD, Paper presented at the Society for Biological Psychıatry Meeting, May, 1987.

Hamilton, M., A rating scale for depression. J. Neurol. Neurosurg. Psychiatry, 23 (1960) 56-62.

Haskett, R.F., Factors affecting outcome after successful elec troconvulsive therapy. Psychopharmacol. Bull.. 18 (1982) $75-78$.

Haskett, R.F. and Albala, A.A., Relevance of neuroendocrinc strategies in electroconvulsive therapy research. Psychopharmacol. Bull., 18 (1982) 57-62.

Holsboer, F., Liebl, R. and Hofschuster, E., Repeated dexamethasone suppression tests during depressive illness. J Affect. Disord. 4 (1982) 93-101.

Holsboer, F., Steiger, A. and Maier, W., Four cases of rever. sion to abnormal dexamethasone suppression test response as an indicator of clinical relapse: a preliminary report. Biol. Psychiatry, 18 (1983) 911.

Murphy, B.E.P., Some studies of the protein-binding of steroids and their application to the routine micro- and ultramicro-measurement of various steroids in body fluids by competitive protein-binding radioassay, $\mathrm{J}$. Clin. Endocrinol. Metabol, 27 (1967) 973-990

Papakostas, Y.. Fink, M., Lee, J. et al., Neuroendocrine measures in psychiatric patients: course and outcome with ECT, Psychiatry Res., 4 (1981) 5564

Privitera, M.R., Greden, J.F., Gardner, R.W. et al., Inter. ference by carbamazepine with the dexamethasone suppression test, Biol. Psychiatry, 17 (1982) 611-620.

Spitzer, R.L. and Endicott, J., Schedule for Affective Disorders and Schizophrenia. Biometrics Research Division. New Y'ork State Psychiatric Institute, New York. 1975

Spitzer, R.L., Endicott, J. and Robins, E., Research Diagnostic Criteria for a Selected Group of Function Disorders, 3rd edn., Biometrics Research Division, New York State Psy. chiatric Institute, New York, 1977.

Targum. S.D., The application of serial neuroendocrine challenge studies in the management of depressive disorder. Biol. Psychiatry, 18 (1983) 3. 19. 